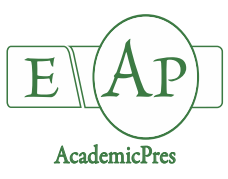

Cruceriu D et al. (2020)

Notulae Botanicae Horti Agrobotanici Cluj-Napoca 48(1):24-39

DOI: $10.15835 /$ nbha4811178

Research Article

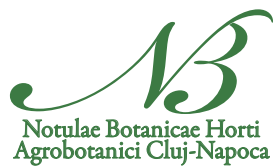

\title{
Biochemical profile, selective cytotoxicity and molecular effects of Calendula officinalis extracts on breast cancer cell lines
}

\section{Daniel CRUCERIU ${ }^{1,2}$, Zorita DIACONEASA ${ }^{3}$, Sonia SOCACI ${ }^{3}$, Carmen SOCACIU ${ }^{3}$, Elena RAKOSY-TICAN ${ }^{1 *}$, Ovidiu BALACESCU ${ }^{2,4}$}

\author{
${ }^{1}$ Babes-Bolyai University, Department of Molecular Biology and Biotechnology, 5-7 Clinicilor Street, Cluj-Napoca 400006, \\ Romania;dani_cruceriu@yahoo.com; rakosy.elena@gmail.com (*correspondingauthor). \\ ${ }^{2}$ The Oncology Institute "Prof. Dr. Ion Chiricuta", Department of Functional Genomics, Proteomics and Experimental Pathology, 34-36 \\ Republicii Street, Cluj-Napoca 400015, Romania; obalacescu@yahoo.com \\ ${ }^{3}$ University of Agricultural Sciences and Veterinary Medicine, Faculty of Food Science and Technology, 3-5 Calea Mănăştur, Cluj-Napoca \\ 400372,Romania;sonia.socaci@usamvcluj.ro; zorita.diaconeasa@gmail.com; carmen.socaciu@usamvcluj.ro \\ ${ }^{4}$ University of Medicine and Pharmacy "Iuliu Hatieganu", 11th Department of Medical Oncology, Cluj-Napoca 400015, Romania
}

\begin{abstract}
Calendula officinalis extracts have been known to possess anti-tumor properties, but questions regarding their mechanisms of action still need to be answered. Therefore, the present study aims to investigate the selective cytotoxicity, the biochemical profile and the corresponding molecular effects of two extracts of $C$. officinalis: flowers and leaves, against several breast cancer cell lines in vitro. Dry flowers and leaves were subjected to ultrasonication assisted extraction in methanol 70\%. The phenolic and volatile profiles of the extracts, determined by HPLC-MS and nontargeted GC-MS, revealed high levels of specific phenolic acids, flavonols and coumarin and several volatile compounds, including mono- and sesquiterpenes, ketones, aldehydes and esters. Both extracts proved to possess selective cytotoxic activities against tumor cells in comparison to healthy endothelial cells, according to the MTT assay. The flower extract was superior in terms of both cytotoxicity and selectivity when compared to the leaf extract, in accordance to their biochemical profiles. The gene expression pattern for 10 genes of interest was evaluated by RT-qPCR. The expression level of several genes involved in apoptosis (BCL2, $B A X, B B C 3, Z M A T 3)$, and cell cycle progression (NFkB, $C C N D 1, S T A T 3$ ) was modulated by the treatment with both extracts. Therefore, $C$. officinalis extracts proved to be rich in compounds characterized by cancer-related cytotoxicity and are capable of inducing selective cytotoxicity on breast cancer cell lines.
\end{abstract}

Keywords: apoptosis; breast cancer; Calendula officinalis; phenolic constituents; proliferation; selective cytotoxicity; volatile constituents

\section{Introduction}

Plants are considered an important resource for medicine in general, and for oncology specifically. They are a prime source of natural compounds, especially secondary metabolites, with wide applications in the 
treatment of different affections and diseases. Between 1940 and 2014, 49\% of all approved drugs for cancer chemotherapy were derived from natural products (Newman and Cragg, 2016). However, only $10 \%$ of all plant species were tested for their pharmacological proprieties (Iqbal et al., 2017), suggesting a great potential for this research area. Besides using plant-derived compounds in current clinical settings as chemotherapeutic drugs, plant extracts, formulations and dietary supplements are also used by cancer patients as complementary and alternative medicine (CAM) products. The overall prevalence of CAM use by cancer patients has increased in the past decades, with $49 \%$ of patients using it after the year 2000 (Horneber et al., 2012). Among CAM treatments, herbal medicine is often found to be the most common therapy (Olaku and White, 2011).

Breast cancer has the highest incidence among women worldwide and is the fifth cause of cancer death overall, with a mortality of 0.62 million in 2018 (Bray et al., 2018). Plant-derived drugs, especially taxanes, are often part of the chemotherapy regimens for breast cancer patients. Taxanes improve chemotherapy efficacy, independently of tumor size, grade or nodal status, while regimens based on anthracyclines and taxanes reduce breast cancer mortality by 30\% (Peto et al., 2012). Furthermore, plant-derived compounds are widely used by breast cancer patients as CAM products. Even though the effectiveness and safety of CAM products are not always proven ( $\mathrm{Hu}$ et al., 2005), 40-80\% of patients with breast cancer report using CAM for both treating their disease and improving the treatment-related symptoms (Saghatchian et al., 2014). Despite the progress made in breast cancer management in the past decades, therapeutic failures are still common in the current clinical practice. The therapeutic options for advanced stage breast carcinoma and specific subtypes like TNBC (Triple Negative Breast Cancer) are still limited and need to be diversified. In addition, taking into consideration that herbal formulations are increasingly being used by breast cancer patients during and after standard cancer therapies, assessment of both their safety and effectiveness is needed in order to establish their potential in cancer management.

Calendula officinalis L (Asteraceae), known as the pot marigold, is a plant widely used in traditional medicine. Its flowers and leaves are used in the treatment of poorly healing wounds, minor bruises, rashes and burns and also in the discomfort alleviation caused by stomach ulcers or inflammation of the oral and pharyngeal mucosa (Mehta et al., 2012). Several pharmacological activities were proven for C. officinalis flower/ leaf herbal preparations, including antioxidant (Frankic et al., 2009), immunostimulant (Varlijen, 1989), wound healing activity (Parente et al., 2012), antibacterial (Efstratiou et al., 2012) antifungal (Gazim et al., 2008) and anti-viral activity (Bogdanova et al., 1970).

C. officinalis extracts of flowers, leaves and roots also possess anti-tumor activities, emphasizing their potential in cancer management (Cruceriu et al., 2018). Several studies report cytotoxic and cytostatic effects in different cancer cell lines in vitro (Matysik et al., 2005; Jimenez-Medina et al., 2006; dos Santos Junior et al., 2010; Wegiera et al., 2012; Matic et al., 2013; Mouhid et al., 2018), while the flower extracts anti-tumor (Jimenez-Medina et al., 2006), chemoprotective (Barajas-Farias et al., 2006; Ali et al., 2014;) and antimetastatic (Preethi et al., 2010) activities were demonstrated in vivo, in animal models. However, several questions regarding the cancer-related cytotoxicity of $C$. officinalis extracts still need to be answered. First of all, the constituents that are responsible for the cytotoxic activity of $C$. officinalis' whole extracts need to be identified. Secondly, the selectivity towards cancer cells compared to healthy cells in regard to the cytotoxic activity needs to be assessed. Thirdly, the molecular mechanisms underlying the cell death and cell cycle arrest effects induced by $C$. officinalis extracts need to be elucidated. 


\section{Materials and Methods}

\section{Plant material and culture conditions}

C. officinalis seeds were collected from Covasna County, Romania, in October 2016. Seeds were germinated and cultivated ex vitro in laboratory conditions (temperature: $21{ }^{\circ} \mathrm{C}$; photoperiod: $16 \mathrm{~h} / 8 \mathrm{~h}$, watering: three times a week) for 12 weeks. Authentication of the plant species was done at the CL Herbarium, Babes-Bolyai University, Romania (specimen voucher 668431). Plant flowers and leaves were collected separately, dried in a dark room and powdered for further analysis.

\section{Cell lines and culture conditions}

Four human cell lines were used in this study: MCF7 (luminal breast cancer cells), MDA-MB-231, Hs578T (triple negative breast cancer cells) and HUVEC (human umbilical vein endothelial cells); cell lines were obtained from the European Collection of Authenticated Cell Cultures. MCF7 cells were cultured in standard conditions in MEM, MDA-MB-231 in RPMI-1640, Hs578T in DMEM and HUVEC in ECM growth media, supplemented with $10 \%$ fetal bovine serum (FBS), $1 \%$ glutamine and $1 \%$ penicillinstreptomycin. Additionally, the MCF7 media was supplemented with $1 \%$ non-essential amino-acids (NEAA), while $0.01 \mathrm{mg} / \mathrm{ml}$ insulin was added to the $\mathrm{Hs} 578 \mathrm{~T}$ media. All cell lines were maintained at $37{ }^{\circ} \mathrm{C}$ in a humidified atmosphere containing $5 \% \mathrm{CO}_{2}$. All cell culture reagents were obtained from Sigma-Aldrich (München, Germany).

\section{Preparation of plant extracts}

Dried powdered plant material ( $5 \mathrm{~g}$ ) was subjected to extraction in methanol $70 \%$ at a liquid-to-solid ratio of 10:1 ml/g, by an ultrasound-assisted extraction (UAE) procedure. Briefly, plant material in extraction solvent was sonicated at a fixed ultrasonic power of $750 \mathrm{~W}$, at $40{ }^{\circ} \mathrm{C}$, in three successive 10 min cycles (Sonics Vibra-cell VC750). The obtained suspension was left for an additional $24 \mathrm{~h}$ period, in the dark, at room temperature for maceration. This homogenate was then centrifuged at $2000 \mathrm{rpm}$ for $5 \mathrm{~min}$ and the supernatant was collected and filtered through a $0.45 \mu \mathrm{m}$ Millipore. The obtained crude methanolic extracts were concentrated to dryness under reduced pressure, at $40{ }^{\circ} \mathrm{C}$, using a vacuum rotary evaporator (Heidolph Laborota 4000 Efficient). Half of the dry residue obtained for each sample (flowers/ leaves) was redissolved in methanol $70 \%$ for future biochemical analysis, while the other half was homogenized in dimethyl sulfoxide (DMSO) for in vitro experiments, both at a concentration of $100 \mathrm{mg} / \mathrm{ml}$ (stock solution). All extracts were filtered once again through a $0.22 \mu \mathrm{m}$ Millipore, before testing.

\section{HPLC-PDA/-ESI+-MS identification and quantification of phenolic compounds}

HPLC analysis of the samples was performed on an Agilent 1200 system equipped with a binary pump delivery system LC-20 AT (Prominence), a degasser DGU-20 A3 (Prominence), a diode array SPD-M20 UVVIS detector (DAD). Separation of the compounds was achieved on an Eclipse XDB C18 column $(4 \mu \mathrm{m}, 4.6$ x $150 \mathrm{~mm}$ ). The mobile phases consisted of solvent A - bidistilled water and $0.1 \%$ acetic acid/acetonitrile (99/1) $\mathrm{v} / \mathrm{v}$, while solvent $\mathrm{B}$ was acetonitrile and acetic acid $0.1 \%$. The gradient elution system was programmed as following: 0-2 min, isocratic with 5\% (v/v) eluent B; $2-18 \mathrm{~min}$, linear gradient from $5 \%$ to $40 \%$ (v/v) eluent B; 18-20 min, linear gradient from $40 \%$ to $90 \%$ (v/v) eluent B; $20-24 \mathrm{~min}$, isocratic on $90 \%$ (v/v) eluent B; 24-25 min, linear gradient from $90 \%$ to $5 \%(\mathrm{v} / \mathrm{v})$ eluent $\mathrm{B} ; 25-30 \mathrm{~min}$, isocratic on $5 \%(\mathrm{v} / \mathrm{v})$ eluent $\mathrm{B}$. Flow rate was set to $0.5 \mathrm{ml} / \mathrm{min}$ and column temperature was maintained at $25^{\circ} \mathrm{C}$. The chromatograms were monitored at $340 \mathrm{~nm}$. Identification of the compounds and peak assignments were done using their retention time, UV-VIS and mass spectra, and also comparing with commercial standards (chlorogenic acid, caffeic acid, quercetinrutinoside, quercetin-glucoside, ellagic acid, myricetin) and previously published literature. For the mass spectrometric measurements, a single quadrupole 6110 mass spectrometer (Agilent Technologies) equipped 
with an ESI probe was used. Measurements were performed in the positive mode with an ion spray voltage of $3000 \mathrm{~V}$, and a capillary temperature of $350^{\circ} \mathrm{C}$. Data were collected in full scan mode within the range 280 to $1000 \mathrm{~m} / \mathrm{z}$. For quantification of phenolic acids and flavonoids, standard curves of chlorogenic acid, gallic acid and rutin were used, respectively.

\section{Non-targeted ITEX/GC-MS headspace analysis of volatile compounds}

The volatile compounds from the headspace of the methanolic extracts of the samples were determined using the in-tube extraction technique (ITEX) coupled with gas-chromatography-mass spectrometry. A volume of each extract was put in a headspace vial and incubated at $60^{\circ} \mathrm{C}$ for $20 \mathrm{~min}$. After the incubation, the extraction of the volatile compounds from the headspace phase was performed using a Combi PAL AOC-5000 autosampler (CTC Analytics) with a headspace syringe ITEX-II equipped with a microtrap (ITEX2TrapTXTA, Tenax TA 80/100 mesh). The volatiles were then directly thermally desorbed into the chromatograph injector. The analysis was carried out on a GCMS QP-2010 (Shimadzu Scientific Instruments) model gas chromatograph - mass spectrometer. The volatile compounds were separated on a Zebron ZB-5 ms capillary column of $30 \mathrm{~m} \times 0.25 \mathrm{~mm}$ i.d and $0.25 \mu \mathrm{m}$ film thickness. The initial column temperature was set at $30^{\circ} \mathrm{C}$ (hold for $2 \mathrm{~min}$ ), increased to $140{ }^{\circ} \mathrm{C}$ with a rate of $5^{\circ} \mathrm{C} / \mathrm{min}$ and then increased to $270^{\circ} \mathrm{C}$ and hold for $5^{\circ} \mathrm{C}$. The carrier gas was helium with a flow rate of $1 \mathrm{~mL} / \mathrm{min}$ and a split ratio of $1: 20$. The injector, ion-source and interface temperatures were set at $250{ }^{\circ} \mathrm{C}$. The MS detection used for the qualitative analysis was performed on a quadrupole mass spectrometer operating in the electron ionization mode (EI) at $70 \mathrm{eV}$. The volatile compounds were recorded in total ion chromatogram (TIC) in full scan $(40-450 \mathrm{~m} / \mathrm{z})$.

The volatile compounds were tentatively identified by first comparing the mass spectrometric information of each chromatographic peak to NIST27 and NIST147 mass spectra libraries (considering a minimum similarity of $85 \%$ ) and then whenever possible by comparison with retention indices drawn from www.pherobase.com or www.flavornet.org (for columns with a similar stationary phase to the ZB-5ms column). This technique offers a qualitative assessment of volatile compounds, so the relative percentage of each compound was estimated as a fraction of its integrated ion area from total ion chromatograms (TIC) area $(100 \%)$.

\section{Selective cytotoxicity assay}

The cytotoxic activity of both $C$. officinalis extracts was evaluated on all four cell lines by the MTT assay (Sigma-Aldrich München, Germany), according to the manufacturer protocol. Briefly, cells were seeded in 96well plates at a density of $2 \times 104$ cells/well. After $24 \mathrm{~h}$, the media was replaced and the extracts were added in nine successive concentrations, varying from $50-1000 \mu \mathrm{g} / \mathrm{ml}$, in six technical replicates. After a $48 \mathrm{~h}$-period of incubation with the extracts, the supernatant was removed, $100 \mu \mathrm{l}$ of the MTT solution $(1 \mathrm{mg} / \mathrm{ml})$ was added onto the cells and left for incubation for $1 \mathrm{~h}$. Subsequently, the MTT solution was removed, $150 \mu \mathrm{l} \mathrm{DMSO}$ was added on cells to solubilize the formed formazan and the absorbance was measured at a wavelength of $570 \mathrm{~nm}$, using a microplate spectrophotometer (Synergy HTX, BioTek, Winooski, VT, USA). All experiments were performed in triplicate.

Cell viability was calculated as the fraction of viable cells compared with the untreated control, based on the absorbance values. The half maximal inhibitory concentration (IC50) values for each extract on each cell line were calculated in GraphPad Prism Software Version 5. The selectivity coefficient in the cytotoxic action for each extract was calculated as the ratio between the IC50 value on the healthy cell line (HUVEC) and the IC50 value obtained for each cancer cell line. HUVEC cells were chosen as a tumor unrelated control, because they are one of the first cell types that come in contact with the anti-tumor compounds administrated in vivo, by forming the inner layer of the vasculature. 
Separate experiments were conducted in the same conditions to evaluate the cytotoxicity of the DMSOvehicle on all four cell lines. The final DMSO concentration did not exceed $1 \%$ on the extract-treated cells and no DMSO-related cytotoxic effects were observed up to this concentration (data not shown).

\section{Expression analysis of apoptosis- and cell cycle-related genes}

The molecular effects of both extracts on MCF7 breast cancer cell line was evaluated by RT-qPCR. Ten well-known genes involved in apoptosis and cell cycle progression were selected for gene expression analysis: BCL2, BAX, BBC3, TP53, CASP3, CASP7, CCND1, NFkB, STAT3 and ZMAT3. Cells were grown in 12well plates at an initial density of $2 \times 105$ cells/well, for $24 \mathrm{~h}$. Each extract was added at the IC 50 concentration in technical duplicates, and the cells were further incubated with the treatments for $48 \mathrm{~h}$. Cells were lysed with TriReagent solution (Sigma-Aldrich München, Germany) and total RNA was extracted using the phenolchloroform method. Total RNA quality and quantity were determined using the Bioanalyzer 2100 (Agilent Technologies). For each sample, 500 ng of RNA were used for the cDNA synthesis step (High-Capacity cDNA Reverse Transcription Kit, Applied BioSystems). The PCR reaction mixture $(10 \mu \mathrm{L})$ contained $2 \mu \mathrm{L}$ LightCycler TaqMan Master (Roche), the specific primer pair at a concentration of $0.5 \mu \mathrm{M}$ each, the UPL probe (Roche) at a concentration of $0.2 \mu \mathrm{M}$ and $2.5 \mu \mathrm{L}$ diluted cDNA (1:10). The primers and the UPL probes used for amplification are presented in Table 1. The RT-qPCR reaction was carried out on a LightCycler 480 (Roche) device. The following cycling conditions were used: denaturation at $95^{\circ} \mathrm{C}$ for $10 \mathrm{~min}$., amplification including 40 cycles of 10 seconds at $95^{\circ} \mathrm{C}, 20$ seconds at $55^{\circ} \mathrm{C}$ and 1 second at $72{ }^{\circ} \mathrm{C}$, final cooling at $40^{\circ} \mathrm{C}$ for 30 seconds. Each amplification was carried out in technical duplicates. The gene expression (fold change) was calculated with the $\Delta \Delta \mathrm{Ct}$ method (Livak and Schmittgen, 2001), the housekeeping gene used for normalization being RN18S1.

Table 1. The primers sequences and the UPL probes used for RT-qPCR

\begin{tabular}{|c|c|c|}
\hline Gene & Primers (Sequence 5'-3') & UPL probe \\
\hline BCL2 & $\begin{array}{l}\text { F: ttgacagaggatcatgctgtactt } \\
\text { R: atctttatttcatgaggcacgtt }\end{array}$ & $\# 6$ \\
\hline BAX & $\begin{array}{l}\text { F: caagaccagggtggttgg } \\
\text { R: cactcccgccacaaagat }\end{array}$ & \#55 \\
\hline $\mathrm{BBC} 3$ & $\begin{array}{l}\text { F: gacctcaacgcacagtacga } \\
\text { R: gagattgtacaggaccctcca }\end{array}$ & \#68 \\
\hline TP53 & $\begin{array}{l}\text { F: ctttgaggtgcgtgtttgtg } \\
\text { R: ccctttcttgcggagattc }\end{array}$ & \#6 \\
\hline CASP3 & $\begin{array}{c}\text { F: tggaattgatgcgtgatgtt } \\
\text { R: tccaaaaattattccttcttcacc }\end{array}$ & \#68 \\
\hline CASP7 & $\begin{array}{l}\text { F: cttggaagagcaagggacag } \\
\text { R: ttatgggccaggcttacatc }\end{array}$ & $\# 2$ \\
\hline CCND1 & $\begin{array}{l}\text { F: gctgtgcatctacaccgaca } \\
\text { R: ttgagcttgttcaccaggag }\end{array}$ & \#17 \\
\hline NFkB & $\begin{array}{l}\text { F: cagtgaagaccacctctcagg } \\
\text { R: tcactgtctcggagctcgt }\end{array}$ & $\# 16$ \\
\hline STAT3 & $\begin{array}{c}\text { F: cctctgccggagaaacagt } \\
\text { R: cattgggaagctgtcactgtag }\end{array}$ & $\# 1$ \\
\hline ZMAT3 & $\begin{array}{l}\text { F: ccaggaaagaagggaatgag } \\
\text { R: gcaagagctgcaacataacaat }\end{array}$ & $\# 2$ \\
\hline
\end{tabular}




\section{Results}

\section{Preparation of plant extracts}

Leaves and flowers of $C$. officinalis represented the plant material subjected for extraction. The ultrasound-assisted extraction (UAE) technique was chosen as the extraction method, due to its proved effectiveness in bioactive compounds extraction from plants, with better extraction yields in comparison to classical methods (Chemat et al., 2017). The solvent used for extraction was methanol 70\%, an organic, polar solvent capable of extracting a wide variety of phytoconstituents with high efficiency (Sulaiman et al., 2011). Furthermore, methanol proved to extract natural compounds with better yields in comparison to other solvents, such as ethanol, isopropanol (Butnariu and Coradini, 2012), distilled water, acetone, chloroform, ethyl acetate or hexane (Dhawan and Gupta, 2017). The total extraction yields for both extracts are presented in Table 2.

Table 2. Total extraction yields for both $C$. officinalis extracts produced by UAE technique

\begin{tabular}{|c|c|c|c|}
\hline Extract & $\begin{array}{c}\text { Input - Plant material DW } \\
(\mathrm{g})\end{array}$ & $\begin{array}{c}\text { Output - Extracted powder } \\
\text { DW }(\mathrm{g})\end{array}$ & $\begin{array}{c}\text { Extraction yield } \\
(\%)\end{array}$ \\
\hline C. officinalis flowers & $5 \mathrm{~g}$ & $1.205 \mathrm{~g}$ & $24.1 \%$ \\
\hline C. officinalis leaves & $5 \mathrm{~g}$ & $1.600 \mathrm{~g}$ & $32 \%$ \\
\hline
\end{tabular}

\section{Phenolic profile of the C. officinalis extracts}

Phenolic compounds in both C. officinalis extracts were identified by HPLC-PDA/ESI+-MS and further quantified using standard curves. Fourteen different phenolic compounds were identified in the $C$. officinalis flower extract, while only twelve were found in the leaf extract (Figure 1; Table 3). Both extracts were characterized by the presence of flavonols (68.5\% in the flower extract; $59.8 \%$ in the leaf extract), quercetin and isorhamnetin derivates being identified in both extracts. Phenolic acids, namely hydroxybenzoic and hydroxycinnamic acids $(25.1 \%$ in the flower extract; $35.6 \%$ in the leaf extract) and coumarins $(6.4 \%$ in the flower extract; $4.6 \%$ in the leaf extract) were also present in the analyzed extracts (Table 3 ).

The major constituents in the flower extract were identified as chlorogenic acid (peak 3; $[\mathrm{M}+\mathrm{H}]+$, $\mathrm{m} / \mathrm{z}=355$ ) among the phenolic acids, and quercetin-3-O-glucosyl-rhamnosyl-glucoside (peak 5; $[\mathrm{M}+\mathrm{H}]+$, $\mathrm{m} / \mathrm{z}=773$ ), isorhamnetin-3-O-galactoside (peak 7; $[\mathrm{M}+\mathrm{H}]+, \mathrm{m} / \mathrm{z}=478$ ), isorhamnetin-3-O-glucosylrhamnoside (peak 10; $[\mathrm{M}+\mathrm{H}]+, \mathrm{m} / \mathrm{z}=624$ ) and isorhamnetin-7-O-rhamnoside (peak 12; $[\mathrm{M}+\mathrm{H}]+$, $\mathrm{m} / \mathrm{z}=479$ ) from the flavonol fraction. All these compounds were found in concentrations higher than $1 \mathrm{mg}$ $/ 100 \mathrm{mg}$ extract $(\mathrm{DW})$ in the flowers methanolic extract. The major phenolic constituents of the leaf extracts were the dihydroxybenzoic acid (peak $1 ;[\mathrm{M}+\mathrm{H}]+, \mathrm{m} / \mathrm{z}=156$ ), isoquercetin (peak $8 ;[\mathrm{M}+\mathrm{H}]+, \mathrm{m} / \mathrm{z}=465$ ) and isorhamnetin-3-O-glucosyl-rhamnoside (peak 10; $[\mathrm{M}+\mathrm{H}]+, \mathrm{m} / \mathrm{z}=624$ ), all being found in concentrations higher than $0.5 \mathrm{mg} / 100 \mathrm{mg}$ extract (DW).

Comparing the phenolic composition of the two C. officinalis extracts, several relevant differences must be highlighted as follow: the hydroxybenzoic acids are the only class of compounds that were found in higher concentrations in the leaf extract, with $57 \%$ more than in the flower extract. On the other hand, the hydroxycinnamic acids had more than twice the concentrations in the flower extract, with a difference of $139 \%$ in comparison to the leaf extract. The flower extract proved to be far superior in the flavonols quantities as well, having almost three times higher concentrations when compared to the leaf extract (difference of $188 \%$ ). The differences found in the flavonols content are mainly due to the isorhamnetin derivates quantities, the quercetin derivates being found in approximately similar concentrations in both extracts. Furthermore, isorhamnetin and isorhamnetin-3-O-glucoside, two of the flavonol constituents, were only detected and quantified in the flower extract of $C$. officinalis. Regarding coumarins, scopoletin-7-O-glucoside had a more 
than three times higher concentration in the flower extract in comparison with the leaf extract (difference of 244\%).

Table 3. Identification and quantification of phenolic compounds in the extracts of $C$. officinalis leaves and flowers. $\mathrm{R}_{\mathrm{t}}$ - retention time; $[\mathrm{M}+\mathrm{H}]^{+}$- molecular ion; $\mathrm{UV} \lambda_{\max }$ - wavelengths of maximum absorption in the visible region

\begin{tabular}{|c|c|c|c|c|c|c|c|}
\hline \multirow{2}{*}{ Class of compounds } & \multirow{2}{*}{$\begin{array}{l}\text { Peak } \\
\text { No. }\end{array}$} & \multirow{2}{*}{$\begin{array}{c}\mathrm{R}_{\mathrm{t}} \\
(\mathrm{min})\end{array}$} & \multirow{2}{*}{$\begin{array}{c}{[\mathrm{M}+\mathrm{H}]^{+}} \\
(\mathrm{m} / \mathrm{z})\end{array}$} & \multirow{2}{*}{$\begin{array}{l}\mathrm{UV} \lambda_{\max } \\
(\mathrm{nm})\end{array}$} & \multirow{2}{*}{ Compound } & \multicolumn{2}{|c|}{$\begin{array}{c}\text { Quantification }(\mu \mathrm{g} / \mathrm{mL} \\
\text { extract) }\end{array}$} \\
\hline & & & & & & $\begin{array}{l}\text { C. officinalis } \\
\text { flowers }\end{array}$ & $\begin{array}{l}\text { C. officinalis } \\
\text { leaves }\end{array}$ \\
\hline $\begin{array}{l}\text { Hydroxybenzoic } \\
\text { acids }(\mathrm{BA})\end{array}$ & 1 & 3.05 & 156,139 & 240 & Dihydroxybenzoic acid & 366.89 & 576.00 \\
\hline \multicolumn{6}{|c|}{ Total BA $^{1}$} & 366.89 & 576.00 \\
\hline \multirow{3}{*}{$\begin{array}{l}\text { Hydroxycinnamic } \\
\text { acids (HBA) }\end{array}$} & 2 & 9.87 & 355 & 320 & $\begin{array}{l}\text { 3-Caffeoylquinic acid } \\
\text { (Neochlorogenic acid) }\end{array}$ & 458.61 & 321.11 \\
\hline & 3 & 11.85 & 355 & 320 & $\begin{array}{c}\text { 5-Caffeoylquinic acid } \\
\text { (Chlorogenic acid) }\end{array}$ & 1261.26 & 386.57 \\
\hline & 11 & 17.00 & 517 & 330 & $\begin{array}{c}\text { 3,5 Dicaffeoylquinic acid } \\
\text { (Isochlorogenic acid A) }\end{array}$ & 842.42 & 365.29 \\
\hline \multicolumn{6}{|c|}{ Total $\mathrm{HBA}^{2}$} & 2562.29 & 1072.97 \\
\hline \multirow{9}{*}{$\begin{array}{l}\text { Flavonols } \\
\qquad(\mathrm{FL})\end{array}$} & 4 & 13.93 & 757,303 & 360,260 & $\begin{array}{l}\text { Q-3-O-rhamnosyl- } \\
\text { rhamnosyl-glucoside }\end{array}$ & 401.66 & 103.05 \\
\hline & 5 & 14.68 & 773,303 & 355,255 & $\begin{array}{l}\text { Q-3-O-glucosyl- } \\
\text { rhamnosyl-glucoside }\end{array}$ & 1165.46 & 423.18 \\
\hline & 6 & 15.34 & 611,303 & 360,250 & $\begin{array}{c}\text { Q-3-O-rutinoside } \\
\text { (Rutin) }\end{array}$ & 374.52 & 402.98 \\
\hline & 7 & 15.77 & 478,317 & 350,250 & I-3-O-galactoside & 1273.79 & 106.05 \\
\hline & 8 & 16.00 & 465,303 & 361,251 & $\begin{array}{l}\text { Q-3-O-glucoside } \\
\text { (Isoquercetin) }\end{array}$ & 243.65 & 591.78 \\
\hline & 9 & 16.15 & 478,317 & 350,250 & I-3-O-glucoside & 634.70 & nd \\
\hline & 10 & 16.53 & 624,317 & 350,260 & $\begin{array}{l}\text { I-3-O-glucosyl- } \\
\text { rhamnoside }\end{array}$ & 1866.82 & 767.72 \\
\hline & 12 & 17.31 & 479,317 & 362,352 & I-7-O-rhamnoside & 1727.26 & 375.56 \\
\hline & 14 & 22.92 & 317 & & Isorhamnetin & 300.53 & nd \\
\hline \multicolumn{6}{|c|}{ Total FL ${ }^{3}$} & 8728.98 & 2985.54 \\
\hline Coumarins $(\mathrm{CM})$ & 13 & 18.07 & 355,193 & 358,261 & S-7-O-glucoside & 740.59 & 215.22 \\
\hline \multicolumn{6}{|c|}{ TOTAL CM ${ }^{3}$} & 740.59 & 215.22 \\
\hline
\end{tabular}

${ }^{1}$ expressed as $\mu$ gallic acid $/ \mathrm{mL} ;{ }^{2}$ expressed as $\mu$ g chlorogenic acid $/ \mathrm{mL} ;{ }^{3}$ expressed as $\mu \mathrm{g}$ rutin $/ \mathrm{mL}$; Q-Quercetin; I-Isorhamnetin; SScopoletin; nd-not detected

Calendula officinalis - flowers

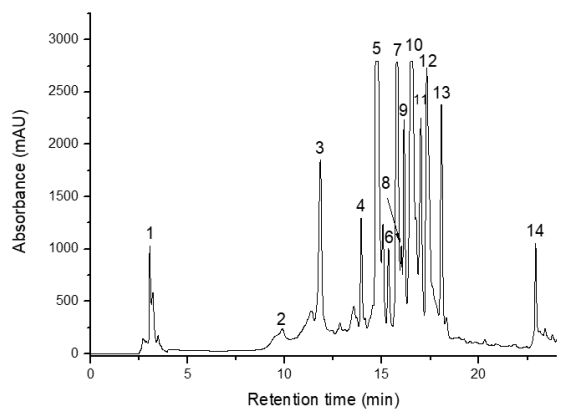

Calendula officinalis - leaves

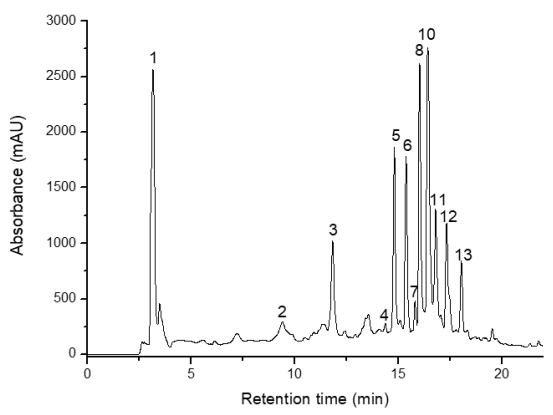

Figure 1. HPLC-PDA chromatograms of phenolic compounds from the extracts of C. officinalis flowers and leaves, recorded at $340 \mathrm{~nm}$ 
Volatile profile of the C. officinalis extracts

The volatile compounds in the methanolic extracts of $C$. officinalis flowers and leaves were identified by ITEX/GC-MS and the relative percentage for each compound was estimated as a fraction of its integrated ion area from total ion chromatograms (TIC) area (100\%). A number of 24 volatile constituents were identified in C. officinalis flower extract, while the leaf extract contained only 16 volatile compounds (Table 4). The volatile compounds identified in the extracts belong to several important secondary metabolites classes: monoterpenes ( $\mathrm{p}$-cymene, limonene, cosmene and alloocimene), sesquiterpenes (cubebene, copaene, muurolene and cadinene), ketones (acetophenone, propiophenone and 2-chloroacetophenone), or volatile aldehydes (benzaldehyde, benzeneacetaldehyde, octanal, decanal and nonanal).

Comparing the volatile profile of the two analyzed extracts, several important differences are observed. First of all, the relative abundance of sesquiterpenes in the flower extract (38.07\%) is much higher than in the leaf extract (4.65\%). These substantial differences are due both to the different muurolene content and to the fact that other sesquiterpenes, such as cubebene, copaene and cadinene are only present in the flower extract. On the other hand, the monoterpenes were found in larger percentage in the leaf extract (4.58\%) compared to the flower extract (1.47\%). Nevertheless, the overall relative abundance of the terpenes is significantly higher in the flower extracts. Furthermore, compounds belonging to the volatile aldehydes class (octanal, decanal, nonanal) were found only in the flower extract.

Table 4. Identification and relative quantification of volatile compounds in the extracts of $C$. officinalis flowers and leaves. $\mathrm{R}_{\mathrm{t}}$ - retention time; Relative abundance - relative percentage (\%) of total peaks area

\begin{tabular}{|c|c|c|c|c|c|}
\hline \multirow{2}{*}{ Class of compounds } & \multirow{2}{*}{ Peak. No. } & \multirow{2}{*}{$\mathrm{R}_{\mathrm{t}}(\min )$} & \multirow{2}{*}{ Compound } & \multicolumn{2}{|c|}{ Relative abundance (\%) } \\
\hline & & & & C. officinalis flowers & C. officinalis leaves \\
\hline \multirow{4}{*}{$\begin{array}{c}\text { (Mono-) } \\
\text { Terpenes } \\
\text { (MT) }\end{array}$} & 8 & 14.30 & p-Cymene & 0.35 & 0.96 \\
\hline & 9 & 14.45 & Limonene & 0.32 & 0.38 \\
\hline & 15 & 17.80 & Cosmene & nd & 0.64 \\
\hline & 16 & 18.20 & Alloocimene & 0.8 & 2.6 \\
\hline \multicolumn{4}{|l|}{ Total MT } & 1.47 & 4.58 \\
\hline \multirow{5}{*}{$\begin{array}{c}\text { (Sesqui-) } \\
\text { Terpenes } \\
\text { (ST) }\end{array}$} & 23 & 24.60 & Alpha-Cubebene & 0.59 & nd \\
\hline & 24 & 25.60 & Copaene & 1.01 & nd \\
\hline & 25 & 29.50 & Gamma-Muurolene & 3.15 & 0.73 \\
\hline & 26 & 30.40 & Alpha-Muurolene & 8.81 & 3.92 \\
\hline & 27 & 31.10 & Delta-Cadinene & 24.51 & nd \\
\hline \multicolumn{4}{|l|}{ Total ST } & 38.07 & 4.65 \\
\hline \multirow{5}{*}{ Aldehydes } & 5 & 12.15 & Benzaldehyde & 3.37 & 1.6 \\
\hline & 10 & 15.00 & Benzeneacetaldehyde & 0.62 & 0.26 \\
\hline & 7 & 13.60 & Octanal & 0.28 & nd \\
\hline & 14 & 17.10 & Nonanal & 0.42 & nd \\
\hline & 20 & 20.30 & Decanal & 0.22 & nd \\
\hline \multicolumn{4}{|l|}{ Total } & 4.91 & 1.86 \\
\hline \multirow{3}{*}{ Ketones } & 11 & 15.70 & Acetophenone & 8.89 & 7.08 \\
\hline & 18 & 19.00 & Propiophenone & nd & 0.2 \\
\hline & 21 & 22.70 & 2-Chloroacetophenone & 0.87 & nd \\
\hline \multicolumn{4}{|l|}{ Total KT } & 9.76 & 7.28 \\
\hline \multirow{6}{*}{ Esters } & 2 & 5.90 & Methyl isovalerate & 0.33 & nd \\
\hline & 3 & 7.05 & Butyl acetate & 30.45 & 69.91 \\
\hline & 4 & 10.80 & Methyl hexanoate & 0.1 & nd \\
\hline & 13 & 16.70 & Methyl benzoate & 4.64 & 3.6 \\
\hline & 19 & 19.90 & Methyl Salicylate & 0.31 & nd \\
\hline & 22 & 23.00 & Benzeneacetic acid, .alpha.-oxo-, methyl ester & 1.12 & nd \\
\hline \multicolumn{4}{|l|}{ Total } & 36.95 & 73.51 \\
\hline \multirow{4}{*}{ Others } & 1 & 4.80 & Isobutylaldehyde dimethyl acetal & 0.37 & 0.67 \\
\hline & 6 & 12.70 & 1,1-Dimethoxyhexane & 7.24 & 6.08 \\
\hline & 12 & 16.50 & 2-Methyl-1-phenylpropene & nd & 0.56 \\
\hline & 17 & 18.70 & Benzoic Acid & 1.22 & 0.83 \\
\hline \multicolumn{4}{|l|}{ Total } & 8.83 & 8.14 \\
\hline
\end{tabular}

*nd - not detected 


\section{Selective cytotoxicity assay}

The two extracts from $C$. officinalis leaves and flowers were evaluated for their cytotoxic activity against MCF7, MDA-MB-231 and Hs578T breast cancer cell lines in 9 successive concentrations (50, 100, 150, 200, 250, 350, 500, 750, $1000 \mu \mathrm{g} / \mathrm{ml}$ ), at $48 \mathrm{~h}$ after administration. Both extracts presented dose-dependent cytotoxicity on all three breast cancer cell lines (Figure 2). The half maximal inhibitory concentrations (IC50 values) for each extract on each cell line are presented in Table 5. Administration of extracts at IC50 values caused substantial morphological changes in the cells, besides reducing the number of viable cells (Figure 3). By comparing the IC50 values obtained for the breast cancer cells and the healthy HUVEC cell line, both extracts proved to possess selective cytotoxicity (Table 5).

Both extracts exhibited the strongest cytotoxic activity and thus had the highest selectivity coefficient against the luminal breast cancer cell line MCF7. TNBC cell lines were less sensitive to the extracts, but the $\mathrm{IC}_{50}$ values were still lower than the one determined for HUVECs, in the majority of cases. The extract obtained from $C$. officinalis flowers possessed stronger cytotoxic activity than the one produced from leaves, on all three breast cancer cell lines. Furthermore, it proved to be selective against all cancer cell lines tested, while the leaf extract had no selectivity in the antitumor action in the case of Hs578T cell line.

Table 5. The IC50 values and the selectivity coefficients in the cytotoxic activity for $C$. officinalis flower and leaf extracts against MCF7, MDA-MB-231, Hs578T and HUVEC cell lines, at $48 \mathrm{~h}$ after administration

\begin{tabular}{|c|c|c|c|c|}
\hline \multirow{2}{*}{ Cell line } & \multicolumn{3}{|c|}{ Extracts } \\
\cline { 2 - 5 } & \multicolumn{2}{|c|}{ C. officinalis - flowers } & \multicolumn{2}{c|}{ C. officinalis - leaves } \\
\cline { 2 - 5 } & IC50 $(\mu \mathrm{g} / \mathrm{ml})$ & Selectivity coefficient & IC50 $(\mu \mathrm{g} / \mathrm{ml})$ & Selectivity coefficient \\
\hline MCF7 & $213.4^{* *} \pm 13.7$ & 3.1 & $252.4^{* *} \pm 72.9$ & 2.5 \\
\hline $\begin{array}{c}\text { MDA-MB- } \\
231\end{array}$ & $386.9^{* *} \pm 61.8$ & 1.68 & $519.7^{*} \pm 20.3$ & 1.21 \\
\hline Hs578T & $520.5^{* *} \pm 38.3$ & 1.25 & $749.4^{* *} \pm 99.3$ & 0.84 \\
\hline HUVEC & $651.4^{* *} \pm 8.8$ & - & $631.0^{* *} \pm 33.0$ & - \\
\hline
\end{tabular}

The IC 50 values are represented as mean \pm standard deviation for three biological replicates. The statistical significance was assessed by t-test, by comparing the absorbance of the control cells with the absorbance of the cells treated with the closest concentration to the IC50 value in three independent biological replicates $\left(\mathrm{p}^{*}>0.05 ; \mathrm{p}^{* *}>0.01\right)$.
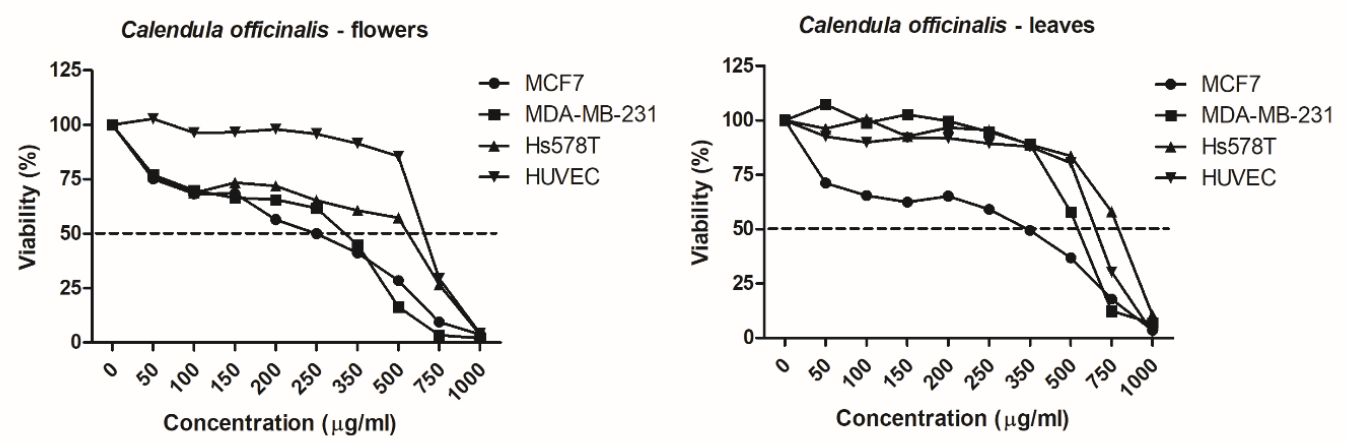

Figure 2. Cytotoxic activity of $C$. officinalis flower and leaf extracts against MCF7, MDA-MB-231, Hs578T and HUVEC cell lines, at $48 \mathrm{~h}$ after administration 


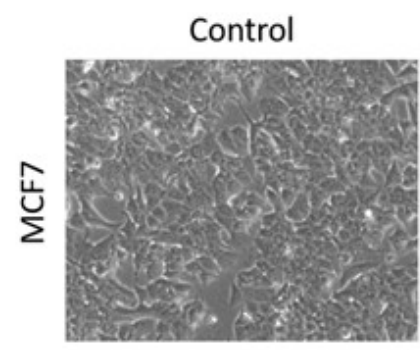

\section{C. officinalis - leaves}
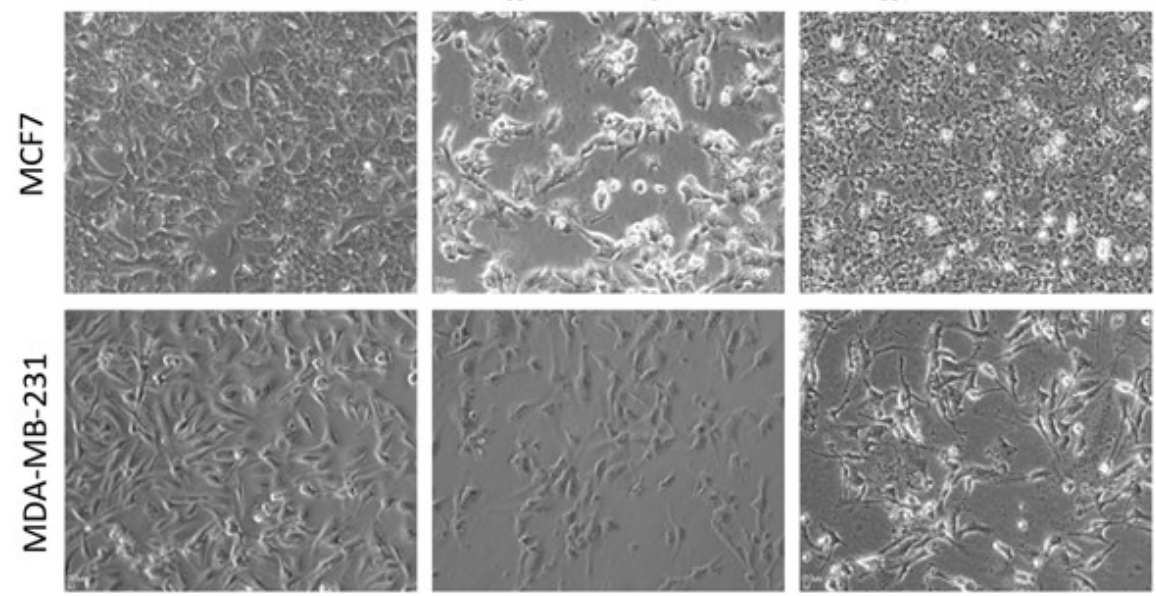

Figure 3. Morphological aspects of MCF7 and MDA-MB-231 cells treated with extracts of $C$. officinalis flowers and leaves, at a concentration equal to IC 50 values, at $48 \mathrm{~h}$ after administration

\section{Expression analysis of apoptosis- and cell cycle-related genes}

The relative expression of 7 apoptosis-related genes (BCL2, BAX, BBC3, TP53, CASP3, CASP7 and $Z M A T 3)$ and 3 genes involved in cell cycle progression and proliferation (CCND1, NFkB and STAT3) was evaluated in MCF7 cell line. MCF7 cell line was selected for the expression analysis due to the good results obtained in the selective cytotoxicity assay. The mRNA levels for all genes in response to both C. officinalis extracts at IC50 concentration were evaluated by RT-qPCR. The expression level of $B C L 2, C C N D 1, N F k B$, $S T A T 3$ was significantly down-regulated, while $B A X, B B C 3$ and $Z M A T 3$ genes were overexpressed in MCF7 cells treated with both extracts. The expression levels of TP53, CASP3 and CASP7 were unaffected by the administration of any of the extracts. The expression levels (fold change) of each affected gene, for both extracts, are presented in Figure 4.
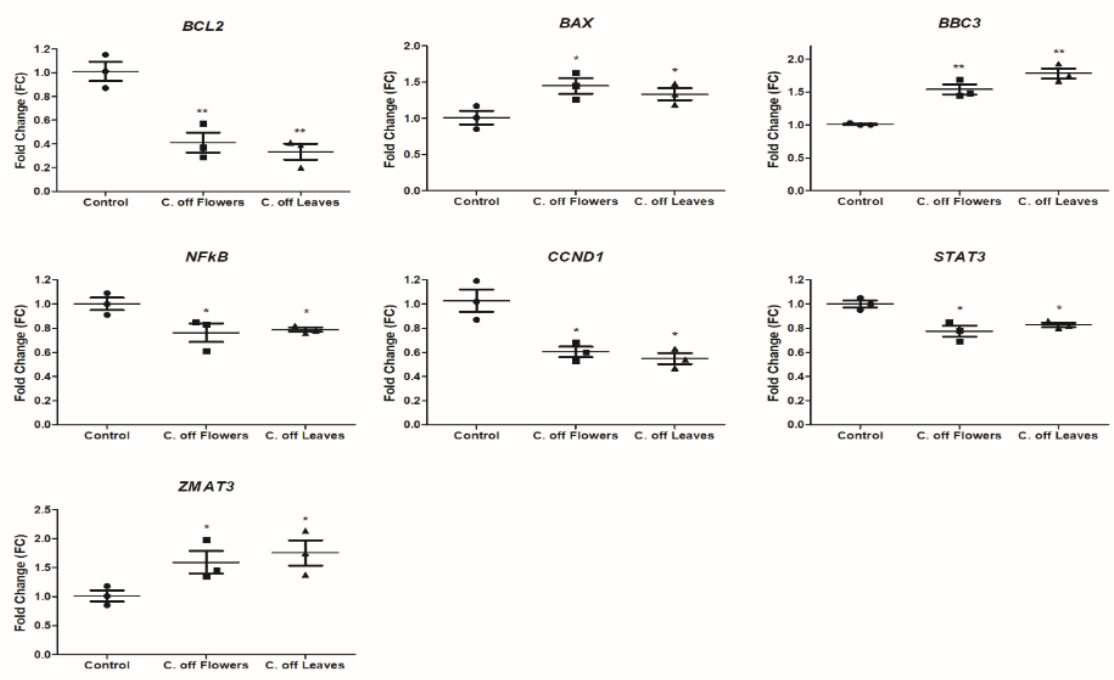

Figure 4. Gene expression of selected apoptosis- and cell cycle-related genes in MCF7 cell line treated with C. officinalis flower and leaf extracts at a concentration equal to IC50 values, at $48 \mathrm{~h}$ after administration. The statistical significance was assessed by t-test $\left({ }^{*} \mathrm{p}<0.05 ;{ }^{* *} \mathrm{p}<0.01\right)$ 


\section{Discussion}

C. officinalis is a well-known plant for its pharmacological activities, including its anti-tumor proprieties. In this context, this study was focused on the selective cytotoxicity of $C$. officinalis derived extracts against breast cancer cell lines, providing new insights in the biochemical composition of the extracts and the corresponding molecular effects in cancer cells.

\section{The biochemical profile of the extracts}

Out of all the phenolic constituents identified in this study, 10 were previously reported in different $C$. officinalis formulations (Mehta et al., 2012; Rigane et al., 2013; Miguel et al., 2016; Olennikov et al., 2017), while four flavonols (dihydroxybenzoic acid, quercetin-3-O-glucosyl-rhamnosyl-glucoside, isorhamnetin-3-Ogalactoside and isorhamnetin-7-O-rhamnoside) were identified for the first time in C. officinalis extracts. Phenolic compounds are known for their cancer-related cytotoxicity, being capable of inhibiting cell proliferation and inducing apoptosis (Nichenametla et al., 2006; Fantini et al., 2015; Lewandowska et al., 2016). Several phenolic compounds identified in the $C$. officinalis extracts used in this study, were previously reported to possess important cytotoxic activities: chlorogenic acid (Yamagata et al., 2018), quercetin derivates (Kashyap et al., 2016), isorhamnetin derivates (Wu et al., 2018) and scopoletin derivates (Li et al., 2015). Therefore, these constituents contributed substantially to the cytotoxic effects of $C$. officinalis extracts on breast cancer cell lines.

A number of 28 volatile compounds were identified in $C$. officinalis extracts, 24 of them being present

in the flower extract and 16 appeared as leaf extract constituents. Our data is consistent with previous reports, which also found cymene, limonene, cubebene, copaene, muurolene, cadinene and nonanal in different $C$. officinalis formulations (Okoh et al., 2007; Gazim et al., 2008; Petrović et al., 2010; Kaškonienè et al., 2011). However, to our knowledge, this is the first-time volatile compounds like octanal and nonanal, cosmene and alloocimene or propiophenone and chloroacetophenone are reported in C. officinalis extracts. Volatile compounds, including mono- and sesquiterpenes are recognized for their cytotoxic potential, both as mixtures of compounds and as individual plant constituents (Greay and Hammer, 2015; Dhifi et al., 2016). Individual volatile compounds found in the C. officinalis extracts used in this study, such as cadinene (Hui et al., 2015), copaene (Turkez et al., 2014), methyl benzoate and multiple acetophenones (Nakamura et al., 2002) were previously reported to possess important cancer-related cytotoxic activities. Consequently, the volatile profile found in the $C$. officinalis extracts might be responsible, in part, for the cytotoxic effects observed on breast cancer cells.

\section{The cancer-related cytotoxicity of the extracts}

The half maximal inhibitory concentration $\left(\mathrm{IC}_{50}\right)$ values ranged between $213.4 \mu \mathrm{g} / \mathrm{ml}$ for the flower extract, on MCF7 cell line, and $749.4 \mu \mathrm{g} / \mathrm{ml}$ for the leaf extract, on Hs578T cell line. Previous studies, investigating $C$. officinalis extracts obtained through classical methods reported much higher $\mathrm{IC}_{50}$ values on various cancer cell lines (Matic et al., 2013); thus, the UAE technique used in this study is an efficient method for bioactive compounds extraction. However, two other methods, the laser activated extraction (JimenezMedina et al., 2006) and the supercritical $\mathrm{CO}_{2}$ extraction (Mouhid et al., 2018) showed better results in terms of cytotoxicity of $C$. officinalis flower extracts.

The highest cytotoxicity for both extracts was observed against MCF7 cell line. MCF7 is a luminal A breast cancer cell line, a less aggressive molecular subtype, which is also often responsive to chemotherapy. On the other hand, MDA-MB-231 and Hs578T are triple-negative, claudin-low breast cancer cell lines, with a phenotype characterized by intermediate to low chemotherapy responsiveness (Holliday and Speirs, 2011). In 
this context, the differences regarding the specific $\mathrm{IC}_{50}$ values between MCF7 cell line and MDA-MB-231/ Hs578T were expected.

Both flower and leaf extracts proved to be selective in their anti-tumor action, with the highest selectivity coefficients against MCF7 cell line. Selective cytotoxicity was previously reported for an aqueous extract obtained from C. officinalis flowers, by comparing its cytotoxicity on several cancer cell lines and on healthy immunocompetent peripheral blood mononuclear cells (PMBCs) (Matic et al., 2013). However, no selectivity was found for a methanol extract obtained from $C$. officinalis flowers, by comparing its action on breast cancer cells and normal human skin fibroblasts (Matysik et al., 2005). Collectively, these results suggest that $C$. officinalis extracts might be selective against tumor cells, but the results are highly dependent on the extraction procedure, and thus the biochemical composition of the extracts and on the cell types used.

Comparing the two C. officinalis preparations used in this study, the flower extract showed better results in terms of the anti-tumor properties on all three breast cancer cell lines. These results are consistent with the only other study that compared the cytotoxicity of the leaves and the flower extracts obtained from C. officinalis on cancer cells, which also found lower cytotoxicity for the leaf extracts, with $\mathrm{IC}_{50}$ values in the same range as the ones reported here (Wegiera et al., 2012). These differences regarding the exerted cytotoxicity might be explained, at least in part, by the distinct phenolic and volatile profiles of the two extracts. The flower extract was superior in regard to both diversity and concentration of phenolic constituents, compounds known for their anti-tumor activity (Nichenametla et al., 2006; Fantini et al., 2015; Lewandowska et al., 2016). It contained two additional flavonols, isorhamnetin and isorhamnetin-3-O-glucoside, had twice as much hydroxycinnamic acids and three times higher concentrations of flavonols and coumarins. Furthermore, several volatile compounds that were previously reported as anti-cancer agents, such as delta-cadinene (Hui et al., 2015) and copaene (Turkez et al., 2014), were identified in the flower extract but not in the leaf extract.

\section{Molecular effects triggered by the extracts in breast cancer cells}

C. officinalis extracts exert their cytotoxic activity on cancer cells by induction of apoptosis (JimenezMedina et al., 2006; Wegiera et al., 2012; Mouhid et al., 2018) and cell cycle arrest in the G0/G1 phase (Jimenez-Medina et al., 2006). It has been demonstrated that both caspase 3 and caspase 7 are activated (cleaved) at the protein level in response to $C$. officinalis extracts administration, and thus apoptosis is induced in a caspase3/7-dependent manner (Jimenez-Medina et al., 2006; Mouhid et al., 2018). On the other hand, the cell cycle arrest effect of $C$. officinalis extracts on cancer cells is induced by the down-regulation of cyclin D1, D3, A, E and several cyclin-dependent kinases (CDKs) (Jimenez-Medina et al., 2006). Besides these molecular effects, there is no other data in the literature regarding the mechanistic underlying C. officinalis cytotoxic actions.

$B C L 2, B A X$ and $B B C 3$ genes encode proteins members of the BCL2 family, which form homo- and heterodimers and function as apoptosis regulators by controlling the mitochondrial membrane permeability, cytochrome $\mathrm{c}$ release from the mitochondria and thus caspase activation. Our data have revealed that $B C L 2$, one of the most important antiapoptotic genes, was down-regulated in breast cancer cells treated with $C$. officinalis extracts. On the other hand, $B A X$ and $B B C 3$, two proapoptotic genes, were up-regulated in response to $C$. officinalis extracts. Therefore, cytochrome $c$ release from the mitochondria could be stimulated by the both tested extracts, and thus apoptosis is most probably implemented through caspase activation, as was shown by previous reports (Jimenez-Medina et al., 2006; Mouhid et al., 2018). The expression of ZMAT3, a gene involved in both tumor cell growth and apoptosis (Bersani et al., 2014), was also investigated in relation with C. officinalis extracts. Our results confirm the induction of this gene in response to both $C$. officinalis extracts, emphasizing the role of these bioactive formulations in the modulation of tumor cell growth inhibition and induction of apoptosis. 
Cell proliferation is controlled by multiple signaling networks, several regulatory proteins as cyclins and transcription factors like NFkB or STAT3 being crucial for cell cycle progression. CCNDI encodes cyclin D1, the regulatory component of the cyclin D-CDK4/6 complex, which induces the G1/S transition during the cell cycle. Cyclin D1 was found down-regulated at the protein level in response to C. officinalis extracts (Jimenez-Medina et al., 2006), while this report shows that its expression is down-regulated starting at the mRNA level. NFkB is a transcription factor that is activated by a wide variety of internal and external stimuli, its activation being associated with cell proliferation. STAT3 is another transcription activator that mediates cellular responses to cytokines and various growth factors, being involved in the G1/S transition of the cell cycle. Its activation leads to the expression of key genes for proliferation, like CCND1. Our data confirmed the down regulation of $C C N D 1$ in relation with $C$. officinalis extracts, but also demonstrated the down-regulation of both $N F k B$ and STAT3 transcription factors. Taken together, these data highlight important molecular changes that contribute to the inhibition of cell cycle progression induced by $C$. officinalis extracts.

No significant deregulation in the expression levels was observed at the mRNA level for caspases 3 and 7 or for the TP53 gene, in response to the administration of the C. officinalis extracts. TP53 encodes a tumor suppressor protein which is activated by multiple cellular stresses and induces cell cycle arrest, apoptosis, senescence and DNA repair. Even though it is not up-regulated at the mRNA level in response to $C$. officinalis extracts, its activation state might be affected by the treatment. Further investigations are needed in this regard. Caspase 3 and 7, effector proteins in the apoptotic process, are activated at the protein level by both intrinsic and extrinsic mechanisms to induce the degradation of cellular components. In C. officinalis treated cells, they are activated at the protein level and thus apoptosis is induced (Mouhid et al., 2018), but no deregulation is observed at the mRNA level according to our results.

\section{Conclusions}

Collectively, our results bring new useful information regarding the biochemical profile and the molecular effects on breast cancer cells of $C$. officinalis extracts. Several compounds belonging to the phenolic and volatile classes of compounds were identified for the first time in C. officinalis formulations. Both leaf and flower extracts proved to possess selective cytotoxic activity against breast cancer cell lines, the extract obtained from flowers being superior regarding the exerted cytotoxicity. Both extracts were able to modulate the expression of several proliferation- and apoptosis-related genes, proving, at the molecular level, the cellular effects previously reported for $C$. officinalis preparations.

\section{Acknowledgements}

This work was supported by a grant of Ministry of Research and Innovation, CNCS - UEFISCDI, project number PN-III-P1-1.1-TE-2016-0973, within PNCDI III.

\section{Conflict of Interests}

The authors declare that there are no conflicts of interest related to this article. 


\section{References}

Ali F, Khan R, Khan AQ, Lateef MA, Maqbool T, Sultana S (2014). Assessment of augmented immune surveillance and tumor cell death by cytoplasmic stabilization of $\mathrm{p} 53$ as a chemopreventive strategy of 3 promising medicinal herbs in murine 2stage skin carcinogenesis. Integrative Cancer Therapies 13(4):351-367.

Barajas-Farias LM, Perez-Carreon JI, Arce-Popoca E, Fattel-Fazenda S, Aleman-Lazarini L, Hernandez-Garcia S (2006). A dual and opposite effect of Calendula officinalis flower extract: chemoprotector and promoter in a rat hepatocarcinogenesis model. Planta Medica 72(3):217-221.

Bersani C, Xu LD, Vilborg A, Lui WO, Wiman KG (2014). Wig-1 regulates cell cycle arrest and cell death through the p53 targets FAS and 14-3-3sigma. Oncogene 33(35):4407-4417.

Bogdanova NS, Nikolaeva IS, Shcherbakova LI, Tolstova TI, Moskalenko N, Pershin GN (1970). Farmakologiia i toksikologiia [Study of antiviral properties of Calendula officinalis]. 33(3):349-355.

Bray F, Ferlay J, Soerjomataram I, Siegel RL, Torre LA, Jemal A (2018). Global cancer statistics 2018: GLOBOCAN estimates of incidence and mortality worldwide for 36 cancers in 185 countries. CA: A Cancer Journal for Clinicians 68(6):394424.

Butnariu M, Coradini CZ (2012). Evaluation of biologically active compounds from Calendula officinalis Flowers using spectrophotometry. Chemistry Central journal 6:35-43.

Chemat F, Rombaut N, Sicaire AG, Meullemiestre A, Fabiano-Tixier AS, Abert-Vian M (2017). Ultrasound assisted extraction of food and natural products. Mechanisms, techniques, combinations, protocols and applications. A review. Ultrasonics Sonochemistry 34:540-560.

Cruceriu D, Balacescu O, Rakosy E (2018). Calendula officinalis: potential roles in cancer treatment and palliative care. Integrative Cancer Therapies 17(4):1068-1078.

Dhawan D, Gupta J (2017). Comparison of different solvents for phytochemical extraction potential from Datura metel plant leaves. International Journal of Biological Chemistry 11(1):17-22.

Dhifi W, Bellili S, Jazi S, Bahloul N, Mnif W (2016). Essential Oils' chemical characterization and investigation of some biological activities: a critical review. Medicines 3(4):123-141.

dos Santos Junior HM, Oliveira DF, de Carvalho DA, Pinto JM, Campos VA, Mourao AR (2010). Evaluation of native and exotic Brazilian plants for anticancer activity. Journal of Natural Medicines 64(2):231-238.

Efstratiou E, Hussain AI, Nigam PS, Moore JE, Ayub MA, Rao JR (2012). Antimicrobial activity of Calendula officinalis petal extracts against fungi, as well as Gram-negative and Gram-positive clinical pathogens. Complementary Therapies in Clinical Practice 18(3):173-176.

Fantini M, Benvenuto M, Masuelli L, Frajese GV, Tresoldi I, Modesti A, Bei R (2015). In vitro and in vivo antitumoral effects of combinations of polyphenols, or polyphenols and anticancer drugs: perspectives on cancer treatment. International Journal of Molecular Sciences 16(5):9236-9282.

Frankic T, Salobir K, Salobir J (2009). The comparison of in vivo antigenotoxic and antioxidative capacity of two propylene glycol extracts of Calendula officinalis (marigold) and vitamin E in young growing pigs. Journal of Animal Physiology and Animal Nutrition 93(6):688-694.

Gazim ZC, Rezende CM, Fraga SR, Svidzinski TI, Cortez DA (2008). Antifungal activity of the essential oil from Calendula officinalis L. (Asteraceae) growing in Brazil. Brazilian Journal of Microbiology [Publication of the Brazilian Society for Microbiology] 39(1):61-63.

Greay SJ, Hammer KA (2015). Recent developments in the bioactivity of mono- and diterpenes: anticancer and antimicrobial activity. Phytochemistry Reviews 14(1):6.

Holliday DL, Speirs V (2011). Choosing the right cell line for breast cancer research. Breast Cancer Research BCR 13(4):215227.

Horneber M, Bueschel G, Dennert G, Less D, Ritter E, Zwahlen M (2012). How many cancer patients use complementary and alternative medicine: a systematic review and metaanalysis. Integrative Cancer Therapies 11(3):187-203.

Hu Z, Yang X, Ho PC, Chan SY, Heng PW, Chan E (2005). Herb-drug interactions: a literature review. Drugs 65(9):12391282. 
Hui LM, Zhao GD, Zhao JJ (2015). Delta-cadinene inhibits the growth of ovarian cancer cells via caspase-dependent apoptosis and cell cycle arrest. International Journal of Clinical and Experimental Pathology 8(6):6046-6056.

Iqbal J, Abbasi B, Mahmood T, Kanwal S, Ali B, Shah SA, Khalil AT (2017). Plant-derived anticancer agents: A green anticancer approach. Asian Pacific Journal of Tropical Biomedicine 7(12):21.

Jimenez-Medina E, Garcia-Lora A, Paco L, Algarra I, Collado A, Garrido F (2006). A new extract of the plant Calendula officinalis produces a dual in vitro effect: cytotoxic anti-tumor activity and lymphocyte activation. BMC Cancer 6:119132.

Kashyap D, Mittal S, Sak K, Singhal P, Tuli HS (2016). Molecular mechanisms of action of quercetin in cancer: recent advances. Tumour Biology 37(10):12927-12939.

Kaškonienè V, Kaškonas P, Jalinskaite M, Maruška A (2011). Chemical Composition and chemometric analysis of variation in essential oils of Calendula officinalis L. during vegetation stages. Chromatographia 73(1):163-169.

Lewandowska H, Kalinowska M, Lewandowski W, Stepkowski TM, Brzoska K (2016). The role of natural polyphenols in cell signaling and cytoprotection against cancer development. The Journal of Nutritional Biochemistry 32:1-19.

Li L, Zhao P, Hu J, Liu J, Liu Y, Wang Z (2015). Synthesis, in vitro and in vivo antitumor activity of scopoletin-cinnamic acid hybrids. European Journal of Medicinal Chemistry 93:300-307.

Livak KJ, Schmittgen TD (2001). Analysis of relative gene expression data using real-time quantitative PCR and the 2(-Delta Delta C(T)) Method. Methods 25(4):402-408.

Matic IZ, Juranic Z, Savikin K, Zdunic G, Nadvinski N, Godevac D (2013). Chamomile and marigold tea: chemical characterization and evaluation of anticancer activity. Phytotherapy Research 27(6):852-858.

Matysik G, Wojciak-Kosior M, Paduch R (2005). The influence of Calendulae officinalis flos extracts on cell cultures, and the chromatographic analysis of extracts. Journal of pharmaceutical and biomedical analysis 38(2):285-292.

Mehta D, Rastogi P, Kumar AK (2012). Review on Pharmacological Update: Calendula officinalis Linn. Inventi Impact: Planta Activa 2012(4):195-204.

Miguel M, Barros L, Pereira C, Calhelha RC, Garcia PA, Castro M (2016). Chemical characterization and bioactive properties of two aromatic plants: Calendula officinalis L. (flowers) and Mentha cervina L. (leaves). Food and Function 7(5):22232232.

Mouhid L, Gomez de Cedron M, Vargas T, Garcia-Carrascosa E, Herranz N, Garcia-Risco M (2018). Identification of antitumoral agents against human pancreatic cancer cells from Asteraceae and Lamiaceae plant extracts. BMC Complementary and Alternative Medicine 18(1):254-262.

Nakamura ES, Kurosaki F, Arisawa M, Mukainaka T, Okuda M, Tokuda H (2002). Cancer chemopreventive effects of constituents of Caesalpinia ferrea and related compounds. Cancer Letters 177(2):119-124.

Newman DJ, Cragg GM (2016). Natural products as sources of new drugs from 1981 to 2014. Journal of Natural Products 79(3):629-661.

Nichenametla SN, Taruscio TG, Barney DL, Exon JH (2006). A review of the effects and mechanisms of polyphenolics in cancer. Critical Reviews in Food Science and Nutrition 46(2):161-183.

Okoh OO, Sadimenko AA, Afolayan AJ (2007). The effects of age on the yield and composition of the essential oils of Calendula officinalis. Journal of Applied Sciences 7(23):3806-3811.

Olaku O, White JD (2011). Herbal therapy use by cancer patients: a literature review on case reports. European Journal of Cancer 47(4):508-514.

Olennikov DN, Kashchenko NI, Chirikova NK, Akobirshoeva A, Zilfikarov IN, Vennos C (2017). Isorhamnetin and quercetin derivatives as anti-acetylcholinesterase principles of marigold (Calendula officinalis) flowers and preparations. International Journal of Molecular Sciences 18(8):225-264.

Parente LM, Lino Junior Rde S, Tresvenzol LM, Vinaud MC, de Paula JR, Paulo NM (2012). Wound healing and antiinflammatory effect in animal models of Calendula officinalis L. growing in Brazil. Evidence-Based Complementary and Alternative Medicine eCAM 2012:375671.

Peto R, Davies C, Godwin J, Gray R, Pan HC, Clarke M (2012). Comparisons between different polychemotherapy regimens for early breast cancer: meta-analyses of long-term outcome among 100,000 women in 123 randomised trials. Lancet 379(9814):432-444. 
Petrović L, Lepojević Z, Sovilj V, Adamović DVT (2010). Composition of essential oil obtained from tubular, head and ligulate flowers of Calendula officinalis L. by steam distillation of plant material and $\mathrm{CO}_{2}$ extracts. Journal of Essential Oil Research 22(2):4.

Preethi KC, Siveen KS, Kuttan R, Kuttan G (2010). Inhibition of metastasis of B16F-10 melanoma cells in C57BL/6 mice by an extract of Calendula officinalis L flowers. Asian Pacific Journal of Cancer Prevention 11(6):1773-1779.

Rigane G, Younes SB, Ghazghazi H, Salem R (2013). Investigation into the biological activities and chemical composition of Calendula officinalis L. growing in Tunisia. International Food Research Journal 20(6):3001-3008.

Saghatchian M, Bihan C, Chenailler C, Mazouni C, Dauchy S, Delaloge S (2014). Exploring frontiers: use of complementary and alternative medicine among patients with early-stage breast cancer. Breast 23(3):279-285.

Sulaiman SF, Sajak AAB, Ooi KL, M. SE (2011). Effect of solvents in extracting polyphenols and antioxidants of selected raw vegetables. Journal of Food Composition and Analysis 24(4-5):506-516.

Turkez H, Togar B, Tatar A, Geyıkoglu F, Hacımuftuoglu A (2014). Cytotoxic and cytogenetic effects of $\alpha$-copaene on rat neuron and N2a neuroblastoma cell lines. Biologia 69(7):936-943.

Varlijen J (1989). Structural analysis of rhamnoarabinogalactans and arabinogalactans with immunostimulating activity from Calendula officinalis. Phytochemistry 28:2379-2384.

Wegiera M, Smolarz HD, Jedruch M, Korczak M, Kopron K (2012). Cytotoxic effect of some medicinal plants from Asteraceae family on J-45.01 leukemic cell line--pilot study. Acta Poloniae Pharmaceutica 69(2):263-268.

Wu Q, Kroon PA, Shao H, Needs PW, Yang X (2018). Differential effects of quercetin and two of its derivatives, isorhamnetin and isorhamnetin-3-glucuronide, in inhibiting the proliferation of human breast-cancer MCF-7 cells. Journal of Agricultural and Food Chemistry 66(27):7181-7189.

Yamagata K, Izawa Y, Onodera D, Tagami M (2018). Chlorogenic acid regulates apoptosis and stem cell marker-related gene expression in A549 human lung cancer cells. Molecular and Cellular Biochemistry 441(1-2):9-19.
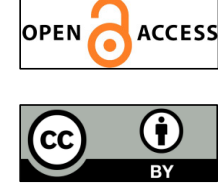

The journal offers free, immediate, and unrestricted access to peer-reviewed research and scholarly work. Users are allowed to read, download, copy, distribute, print, search, or link to the full texts of the articles, or use them for any other lawful purpose, without asking prior permission from the publisher or the author.

License - Papers published in Notulae Botanicae Horti Agrobotanici Cluj-Napoca are Open-Access, distributed under the terms and conditions of the Creative Commons Attribution (CC BY) License. (c) Articles by the authors; UASVM, Cluj-Napoca, Romania. The journal allows the author(s) to hold the copyright/to retain publishing rights without restriction. 